\title{
Effect of graded levels of Moringa oleifera leaf meal on performance and serum biochemical parameters of broiler chickens
}

\author{
Egu, U. N. \\ Department of Animal Science and Fisheries, Abia State University PMB 7010, Umuahia, Nigeria. \\ Email: ucheegu1@gmail.com
}

Copyright @ 2019 Egu. This article remains permanently open access under the terms of the Creative Commons Attribution License 4.0, which permits unrestricted use, distribution, and reproduction in any medium, provided the original work is properly cited.

Received 1st October, 2018; Accepted 12th November, 2018

\begin{abstract}
Ninety-six (96) CHI broiler chickens aged 4 weeks were used to determine the effect of Moringa oleifera leaf meal (MOLM) on growth performance and serum biochemical parameters. The 96 broiler chickens were randomly allocated to 4 treatment groups, identified as $T_{1}, T_{2}, T_{3}$ and $T_{4}$. Each treatment group consisted of 24 birds replicated 3 times with 8 birds per replicate in a Completely Randomized Design (CRD) with four levels of Moringa leaf meal as treatments. The levels of Moringa leaf meal were $0.00 \%, 6.00 \%, 8.00 \%$ and $10.00 \%$. Treatment one $\left(\mathrm{T}_{1}\right)$ which contained no Moringa leaf meal served as the control. The birds in each treatment group were randomly assigned to Moringa leaf meal for 28 days. The birds were fed twice daily, morning and evening. Water was given ad libitum to the birds. The results showed that there were significant differences $(P<0.05)$ among the treatment groups in final body weight, average daily weight gain, average total weight gain, average total feed intake, average daily feed intake and feed conversion ratio. However, there were no significant differences $(P>0.05)$ among the treatment groups in initial body weight. The results further showed that there were significant differences $(P<0.05)$ among the treatment groups in all the serum biochemical parameters measured: urea, cholesterol, glucose and calcium except Aspartate transaminase which was similar $(P>0.05)$ among the treatment groups. The results of this study indicate that Moringa oleifera leaf meal enhanced growth performance: weight gain, feed intake and feed conversion ratio, in the treated birds compared to the control group with the best result at $8.00 \%$ inclusion level. Feeding the birds with MOLM brought about changes in the serum biochemical parameters but without any deleterious effect on them.
\end{abstract}

Keywords: Broilers, Moringa oleifera, performance, serum biochemistry.

\section{INTRODUCTION}

Scarcity of conventional feed ingredients and rising cost of poultry feed have compelled researchers in developing countries to direct their attention to non-conventional feeds, with particular emphasis on protein substitute (Gadzirayi et al., 2012). Moringa oleifera is among plants that can be used as a cheap protein supplement to improve digestibility of other diets. Moringa oleifera is native to India, Red sea, and some parts of Africa including Madagascar (Onu and Aniebo, 2011). Moringa oleifera tree contains high crude protein (CP) in the leaves $(125 \mathrm{~kg}$ DM) and negligible content of tannins and other antinutritive compounds. It offers an alternative source of protein to ruminants and non-ruminants. Half the protein content can be extracted from the leaves in the form of a concentrate that can be added to chicken feed (Onu and Aniebo, 2011). According to Fuglie (2013), the nutrient value of Moringa oleifera leaves can be increased for chickens through the addition of phytase to break down phytate leading to increased absorption of phosphorus. If uncontrolled, raw Moringas added to poultry diets can be dangerous because of high bio-availability of protein, therefore particular care must be taken to avoid excessive protein intake (Gadzirayi et al., 2012).

The serum is the plasma content of the blood which 
lacks coagulating factors. It is similar to intestinal fluid in which the correct composition of key ions acting as electrolytes is essential for normal functioning of muscles and nerves. Other components in the serum include proteins which assist with maintaining $\mathrm{pH}$ and osmotic balance while giving viscosity to the blood; antibodies, or specialized proteins that are important for defense against viruses and bacteria; lipids, including cholesterol, which are transported in the serum; and various other substances including nutrients, hormones, metabolic waste, and external substances, such as drugs, viruses and bacteria (Martin, 2007).

The active constituents in the leaves of Moringa oleifera are glucosinolates e.g., 4 (alpha-L-rhamanosyloxy) benzyl glucosinolate which yield 4 (alpha-L-rhamanosyloxy) benzyl isocyanate following enzymatic degradation with myrosinase. Phenol carboxylic acid and fatty acid including oleic acid (60 to $70 \%)$, palmitic acid (3-12\%), stearic acid (3-12\%) as well eicosanoic acid and lignoceric acid in addition to mustard oil and other constituents.

Ayssiwede (2011), found that MOLM inclusion in the diet up to $24 \%$ did not cause any adverse impact on live body weight, average daily weight gain, feed conversion ratio (FCR), mortality, carcass and organ characteristics in birds compared to their controls. According to Kwedibana (2008), Moringa fed in high quantities (7.5 and 10\%) to one-week old chicks resulted in reduced growth, indicating that higher levels of Moringa in chick diets has a detrimental effect on chick growth. Olugbemi et al (2008) and Onu and Otuma (2010) in Nigeria investigated the effect of MOLM in the performance and blood chemistry of starter broilers and found that MOLM could be included at $7.5 \%$ in broiler diets without any deleterious effects on performance and blood characteristics of broilers. A study by Sarwatt et al. (2012) found that Moringa oleifera when partially used to replace fish meal may hamper growth rate of broiler chickens. In Bostwana, John and Kenuleone (2014), evaluated the effect of MOLM at $10 \%$ inclusion level on the growth rate of broilers and found that commercial broiler diet significantly $(\mathrm{P}<0.05)$ promoted high weight gain $(1.04 \mathrm{~kg})$ than MOLM. On the other hand, FCR was higher for birds on MOLM than those fed commercial diets. In Zimababwe, Fuglie (2009) investigated the effect of supplementing soya bean meals with MOLM as a protein source in poultry and found no significant differences in feed conversion ratio. In a work carried out by Ewuola et al. (2012) on the haematological and serum biochemical response of growing rabbits fed graded levels of MOLM, no significant difference was obtained for the Aspartate amino transferase, Alanine amino transferase and Alkaline phosphatase activities between those fed control diet and $5 \%, 10 \%$ and $15 \%$ MOLM.

This study was carried out to determine the effect of graded levels of Moringa oleifera leaf meal on growth performance and serum biochemical parameters of broiler chickens.

\section{MATERIALS AND METHODS}

\section{Procedure for processing Moringa leaves}

Fresh leaves of Moringa oleifera were harvested within Umudike near Umuahia, Abia State, Nigeria. The harvested leaves were dried under shade at ambient temperature in order to maintain most of the nutrients, green colour and phytochemicals in the leaves according to procedures suggested by Yang and Tsou (2006) (Table 1). The leaflets were stripped from the leaf petiole, washed in $1 \%$ saline solution for 3.5 minutes to remove dirt and microbes. The washed leaflets were drained using plastic buckets and spread on trays made with food-grade mesh before taken to the drier. Drying of leaflets consisted of spreading them thinly on mesh tied on racks in a wellventilated room. The leaves were turned over once a day to improve the drying. The leaves were completely dried to $10 \%$ moisture content. Dried Moringa leaves were milled using a stainless steel harmer mill and sieved to $2 \mathrm{~mm}$ particle size. The dried leaf powder was packaged in dry plastic containers and tagged Moringa oleifera leaf meal (MOLM) (Table 1). This was used to formulate the experimental diet.

\section{Experimental diets}

Four finisher diets (Table 2) were formulated for the birds. Moringa oleifera leaf meal (MOLM) was incorporated into the diets at $0 \%, 6 \%, 8 \%$ and $10 \%$ levels represented as $\mathrm{T}_{1}, \mathrm{~T}_{2}, \mathrm{~T}_{3}$ and $\mathrm{T}_{4}$ respectively. Using NRC (1994), the diets were formulated to provide 20.74 to $27.04 \%$ crude protein and 344.69 to $407.44 \mathrm{kcal} / \mathrm{kg}$. DL- Methionine and Lysine were added into the diets at $0.25 \%$ level each so as to ensure the amino acids were not limiting. The proximate composition of the diets (Table 3 ) were analyzed using the analytical procedures as described by AOAC (2002).

\section{Experimental birds and their management}

Ninety-Six (96), four weeks old broiler chickens of $\mathrm{CHI}$ strain of average body weight of $94.31 \mathrm{~g}$ were used for this study. The birds were sourced from local farmers, reared on deep litter system. A 2- week pre-experimental period was allowed to enable the birds acclimatize. The birds were fed two times daily. Water was provided ad libitum to the birds. The necessary routine management practices were maintained.

\section{Experimental design}

Ninety-Six (96), four weeks old $\mathrm{CHI}$ broiler finishers were used for this experiment. The birds were divided into four treatment groups consisting of 24 birds per treatment 
Table 1. Proximate composition of fresh Moringa leaves and shaded dried Moringa leaf meal (as fed basis).

\begin{tabular}{lcc}
\hline Variable (\%) & FML (\%) & MOLM (\%) \\
\hline Dry matter & 35.10 & 93.80 \\
Crude protein & 6.80 & 22.90 \\
Crude fibre & 1.40 & 9.50 \\
Ether extract & 1.90 & 3.60 \\
Nitrogen free extract & 22.10 & 49.90 \\
Ash & 3.70 & 7.70 \\
\hline
\end{tabular}

$\mathrm{FML}=$ Fresh Moringa Leaves, MOLM= Moringa Leaf Meal.

Table 2. Ingredient Composition of Broiler Finisher Diets containing varying levels of Moringa oleifera Leaf Meal ( $\mathrm{g} / \mathrm{kg})$

\begin{tabular}{lcccc}
\hline Ingredients & $\mathbf{T}_{\mathbf{1}} \mathbf{( 0 \% )}$ & $\mathbf{T}_{\mathbf{2}} \mathbf{( 6 \% )}$ & $\mathbf{T}_{\mathbf{3}} \mathbf{( 8 \% )}$ & $\mathbf{T}_{\mathbf{4}} \mathbf{( 1 0 \% )}$ \\
\hline Maize & 50.0 & 50.0 & 50.0 & 50.0 \\
Soya bean & 28.0 & 22.0 & 20.0 & 18.0 \\
Fish meal & 6.00 & 6.00 & 6.00 & 6.00 \\
PKC & 10.0 & 10.0 & 10.0 & 10.0 \\
Bone meal & 5.00 & 5.00 & 5.00 & 5.00 \\
Salt & 0.25 & 0.25 & 0.25 & 0.25 \\
Premix & 0.25 & 0.25 & 0.25 & 0.25 \\
Methionine & 0.25 & 0.25 & 0.25 & 0.25 \\
Lysine & 0.25 & 0.25 & 0.25 & 0.25 \\
Moringa leaf meal & - & 6.00 & 8.00 & 10.0 \\
Total & 100 & 100 & 100 & 100 \\
& & & & \\
${ }^{*}$ Calculated Crude protein & 27.04 & 23.26 & 22.00 & 20.74 \\
Metabolizable Energy (Kcal/kg) & 407.44 & 369.43 & 354.76 & 344.69 \\
\hline
\end{tabular}

Table 3. Proximate composition of broiler finisher experimental diets.

\begin{tabular}{lrcrc}
\hline Parameters & \multicolumn{1}{c}{$\mathbf{T}_{\mathbf{1}}(\mathbf{0} \%)$} & $\mathbf{T}_{\mathbf{2}}(\mathbf{6 \%})$ & $\mathbf{T}_{\mathbf{3}}(\mathbf{8} \%)$ & $\mathbf{T}_{\mathbf{4}}(\mathbf{1 0} \%)$ \\
\hline Moisture (\%) & $8.67 \pm 0.04$ & $8.64 \pm 0.02$ & $8.64 \pm 0.02$ & $8.63 \pm 0.01$ \\
Crude protein (\%) & $19.37 \pm 0.10$ & $18.7 \pm 0.09$ & $18.55 \pm 0.00$ & $18.52 \pm 0.10$ \\
Crude fibre (\%) & $4.88 \pm 0.04$ & $5.03 \pm 0.06$ & $5.14 \pm 0.09$ & $5.25 \pm 0.07$ \\
Fat (\%) & $8.80 \pm 0.04$ & $8.06 \pm 0.05$ & $7.75 \pm 0.09$ & $7.54 \pm 0.05$ \\
Ash (\%) & $4.90 \pm 0.30$ & $5.08 \pm 0.09$ & $5.15 \pm 0.02$ & $5.20 \pm 0.02$ \\
Carbohydrate (\%) & $53.43 \pm 0.12$ & $54.38 \pm 0.23$ & $54.81 \pm 0.06$ & $55.05 \pm 0.06$ \\
\hline
\end{tabular}

Values are Means \pm standard deviation of duplicate determination.

group. Each treatment group was replicated three (3) times with eight (8) birds per replicate in a Completely Randomized Design (CRD). Four broiler finisher diets were formulated using Moringa leaf meal at $0 \%, 6 \%, 8 \%$ and $10 \%$ inclusion levels, and fed to the birds for 28 days.

The experiment was performed in accordance with the ethical guidelines and regulations of the Abia State University, Uturu, Abia State, Nigeria, and in accordance with internationally accepted principles for laboratory animal use and care.

\section{Data collection}

\section{Growth performance}

At the commencement of the experiment, the birds were weighed and their initial average weight recorded. Thereafter, the birds were weighed every seven (7) days before feeding them. The difference between the preceding week weight and the current weight divided by seven days were the daily weight gain. At the end of the 
feeding trial (28 days) average weight of the birds from different treatment groups were measured to get their final weights while the difference between the initial live weights and the final live weights were the weight gains. The feed fed to the birds were weighed before feeding. Feed intakes were obtained by the difference between the quantity of feed offered and the left over the following morning. Feed conversion ratio (FCR) was calculated as follows:

FCR $=\frac{\text { Quantity of feed consumed }}{\text { Weight gain }}$

\section{Blood chemistry}

At the end of the feeding trial, two broilers from each replicate, making a total of 6 broilers per treatment were randomly selected for breeding. The birds were first stunned and then allowed to gain consciousness, their necks were immediately severed and blood collected from the jugular vein. About two milliliters of blood were collected from each bird and poured into plain bottles where they were allowed to coagulate. The bottles of the coagulated blood were subjected to standard method of serum separation and the harvested sera were used for the evaluation of serum biochemical parameters: urea, cholesterol and glucose were determined following methods described by Baker and Silverton (1986). Aspartate transaminase, Alanine transaminase and Alkaline phosphatase activities were determined using spectrophotometric method as described by Rej and Hoder (1983). The standard flame photometry using Gallenkamp analysis was used to determine serum calcium.

\section{Statistical analysis}

Data collected on performance and serum biochemical parameters of broiler finishers were subjected to one-way analysis of variance (ANOVA) using the technique of Steel and Torrie (2006). Significant treatment means were separated using Duncan's New Multiple Range Test as described by Obi (2002).

\section{RESULTS AND DISCUSSION}

The results of performance of broiler chickens fed graded levels of Moringa oleifera leaf meal are shown in Table 4. There were significant differences $(P<0.05)$ among the treatment groups in final body weight, average daily weight gain, average total weight gain, average daily feed intake, average total feed intake and feed conversion ratio. There were no significant differences $(P>0.05)$ among the treatment groups in initial body weight.

Broiler chickens on $T_{2}$ recorded the highest numerical value of $94.33 \mathrm{~g}$ in initial body weight. The lowest numerical value of $94.30 \mathrm{~g}$ in initial body weight was observed in birds on $T_{1}, T_{3}$ and $T_{4}$. Broiler chickens on $T_{3}$ recorded the highest final body weight of $1779.30 \mathrm{~g}$ and this differed significantly $(P<0.05)$ from birds on $T_{1}$ and $T_{4}$ which were similar $(P>0.05)$ to each other in final body weight. There was no significant difference $(P>0.05)$ between birds on $T_{3}$ and $T_{2}$ in final body weight. The initial and final body weights obtained in the study were lower than the range of 741.60 to $751.00 \mathrm{~g}$ for initial body weights and 1183.00 to $2,070.00 \mathrm{bg}$ for final body weights reported by Egu (2011) in broiler finishers fed enzyme supplemented rice milling waste. This variation in weight could be attributed to breed and nutritional status of the birds.

Broiler chickens on $T_{3}$ recorded the highest value in average daily weight gain of $80.24 \mathrm{~g}$ and this differed significantly $(P<0.05)$ from birds on $T_{1}$ and $T_{4}$ which were similar $(P>0.05)$ to birds on $T_{2}$ in average daily weight gain. There was no significant difference $(P>0.05)$ between broiler chickens on $T_{3}$ and $T_{2}$ in average daily weight gain. The values for average daily weight gain in this study were higher than the range of 40.30 to $44.28 \mathrm{~g}$ reported by Iheukwumere et al. (2008) for broiler chickens fed raw and processed soya bead seed meal.

Broiler chickens on $\mathrm{T}_{3}$ recorded the highest value in average total weight gain $(1685.00 \mathrm{~g})$ and this differed significantly $(P<0.05)$ from broiler chickens on $T_{1}$ and $T_{4}$ which were similar $(P>0.05)$ to birds on $T_{2}$. There was no significant difference $(P>0.05)$ between broiler chickens on $T_{3}$ and $T_{2}$ in average total weight gain. The lowest value in average total weight gain was observed in broiler chickens on $T_{1}(1538.30 \mathrm{~g})$. This may be attributed to decreased nutrients in the diet of the birds since $\mathrm{T}_{1}$ contained $0.00 \%$ Moringa leaf meal.

The inclusion of MOLM in diet of broiler significantly $(P<0.05)$ enhanced the weight gain as compared to control group. The result showed that broiler on $\mathrm{T}_{3}$ fed on Moringa oleifera based diet performed significantly $(P>0.05)$ higher than birds on the control group in terms of higher weight gain. This corroborates the report of Fuglie (2009) and Omer and Hyder (2016) on higher performance of birds fed Moringa oleifera based diet. The rich content of nutrients (Sarwatt et al., 2012) and antimicrobial property of Moringa (Ebenebe et al., 2012) may be responsible for these findings. Moringa oleifera was also reported to have a natural enzyme which aid digestion of fibrous food in the animals (Gaia, 2010). The values for average total weight gain in this study were lower than the range of 2300.40 to $2549.20 \mathrm{~g}$ reported by Odoemelam et al. (2013) for boiler chickens fed Ocimum gratissimum supplemented diets. This disparity in average total weight gain may not be unconnected to the differences in breed and nutritional status of the birds.

The chickens on $T_{4}$ recorded the highest value of 1.41 $\mathrm{kg}$ in average daily feed intake and this differed significantly $(P<0.05)$ from broiler chickens on $T_{1}$ which 
Table 4. Performance of Broiler Chickens Fed Graded levels of Moringa oleifera Leaf Meal.

\begin{tabular}{lccccc}
\hline \multirow{2}{*}{ Parameters } & \multicolumn{3}{c}{ Dietary Level of Leaf Meal (\%) } & \multirow{2}{*}{ SEM } \\
\cline { 2 - 4 } & $\mathbf{T}_{\mathbf{1}}(\mathbf{0 . 0})$ & $\mathbf{T}_{\mathbf{2}} \mathbf{( 6 . 0 )}$ & $\mathbf{T}_{\mathbf{3}} \mathbf{( 8 . 0 )}$ & $\mathbf{T}_{\mathbf{4}} \mathbf{( 1 0 . 0 )}$ & \\
\hline Initial body weight $(\mathrm{g})$ & 94.30 & 94.33 & 94.30 & 94.30 & 0.01 \\
Final body weight $(\mathrm{g})$ & $1632.60^{\mathrm{b}}$ & $1686.00^{\mathrm{ab}}$ & $1779.30^{\mathrm{a}}$ & $1652.63^{\mathrm{b}}$ & 32.48 \\
Av. Daily weight gain $(\mathrm{g})$ & $73.25^{\mathrm{b}}$ & $75.79^{\mathrm{ab}}$ & $80.24^{\mathrm{a}}$ & $74.20^{\mathrm{b}}$ & 1.55 \\
Av. Total weight gain $(\mathrm{g})$ & $1538.30^{\mathrm{b}}$ & $1591.67^{\mathrm{ab}}$ & $1685.00^{\mathrm{a}}$ & $1558.33^{\mathrm{b}}$ & 32.48 \\
Av. Daily feed intake $(\mathrm{kg})$ & $1.29^{\mathrm{b}}$ & $1.33^{\mathrm{ab}}$ & $1.38^{\mathrm{ab}}$ & $1.41^{\mathrm{a}}$ & 0.03 \\
Av. Total feed intake $(\mathrm{kg})$ & $35.99^{\mathrm{b}}$ & $37.24^{\mathrm{ab}}$ & $38.70^{\mathrm{a}}$ & $39.49^{\mathrm{a}}$ & 0.78 \\
Feed conversion ratio & $23.40^{\mathrm{b}}$ & $23.40^{\mathrm{b}}$ & $22.97^{\mathrm{b}}$ & $25.34^{\mathrm{a}}$ & 0.53 \\
\hline
\end{tabular}

ab Means in the same row with different superscript are significantly $(P<0.05)$ different. SEM= Standard error of mean.

Table 5. Serum biochemical parameters of broiler chicken fed graded levels of Moringa oleifera leaf meal.

\begin{tabular}{lccccc}
\hline \multirow{2}{*}{ Parameters } & \multicolumn{3}{c}{ Dietary Level of Leaf Meal (\%) } & \multirow{2}{*}{ SEM } \\
\cline { 2 - 5 } & $\mathbf{T}_{\mathbf{1}}(\mathbf{0 . 0 0})$ & $\mathbf{T . 2}_{\mathbf{2}}(\mathbf{6 . 0 0})$ & $\mathbf{T}_{\mathbf{3}}(\mathbf{8 . 0 0})$ & $\mathbf{T}_{\mathbf{4}}(\mathbf{1 0 . 0 0})$ & \\
\hline Urea $(\mathrm{mg} / \mathrm{dl})$ & $13.50^{\mathrm{a}}$ & $10.50^{\mathrm{a}}$ & $11.50^{\mathrm{a}}$ & $5.00^{\mathrm{b}}$ & 1.82 \\
Cholesterol (mg/dl) & $164.00^{\mathrm{a}}$ & $122.50^{\mathrm{ab}}$ & $116.50^{\mathrm{ab}}$ & $63.50^{\mathrm{b}}$ & 20.62 \\
Glucose (mmol/L) & $142.50^{\mathrm{a}}$ & $101.00^{\mathrm{b}}$ & $93.00^{\mathrm{b}}$ & $84.50^{\mathrm{b}}$ & 12.87 \\
Calcium (mmol/L) & $7.40^{\mathrm{b}}$ & $7.70^{\mathrm{ab}}$ & $7.75^{\mathrm{a}}$ & $7.85^{\mathrm{a}}$ & 0.10 \\
Alkaline phosphatase (iu/L) & $161.00^{\mathrm{a}}$ & $162.00^{\mathrm{a}}$ & $123.50^{\mathrm{b}}$ & $157.00^{\mathrm{a}}$ & 9.19 \\
Alanine transaminase (iu/L) & 0.00 & 0.00 & 0.00 & 0.00 & 0.00 \\
Aspartate transaminase (iu/L) & 89.00 & 89.00 & 89.00 & 89.00 & 0.00 \\
\hline
\end{tabular}

ab Means in the same row with different superscript are significantly $(P<0.05)$ different. SEM= Standard error of mean.

were similar $(P>0.05)$ to those on $T_{2}$ and $T_{3}$ in average daily feed intake. There were no significant differences ( $P>0.05$ ) among broiler chickens on $T_{4}, T_{3}$ and $T_{2}$ in average daily feed intake. The lowest value in average daily feed intake was observed in broiler chickens on $T_{1}$ $(1.29 \mathrm{~kg})$. Average daily feed intake increased as the treatment levels increased. The values for average daily feed intake in this study were higher than the range of 96.41 to $102.40 \mathrm{~g}$ reported by Iheukwumere et al. (2008) for broiler chickens.

Broiler chickens on $T_{4}$ recorded the highest value of $39.49 \mathrm{~kg}$ in average total feed intake and this differed significantly $(P<0.05)$ from broiler chickens on $T_{1}$ which were similar $(P>0.05)$ to those on $T_{2}$ in average total feed intake. There were no significant differences $(P>0.05)$ among broiler chickens on $T_{4}, T_{3}$ and $T_{2}$ in average total feed intake. The lowest value in average total feed intake was observed in birds on $T_{1}(35.99 \mathrm{~kg})$. Average total feed intake increased as the treatment levels increased. The increased feed intake of the Moringa leaf meal fed broilers in this experiment is quite understandable. Moringa leaf meal contained high fibre which tend to increase total fibre content of the diets and dilute other nutrients. The birds tend to eat more feed to meet their energy requirement and sustain rapid growth and development, hence the increased feed intake. This agrees with earlier report (Esonu et al., 2006). The values for average total feed intake in this study were much higher than the range of 4828.73 to $5032.46 \mathrm{~g}$ reported by Odoemelam et al. (2013) for chickens fed Ocimum gratissimum supplemented diets.

The result showed significant differences $(P<0.05)$ among the treatment groups in feed conversion ratio with the broiler chickens on diet $\mathrm{T}_{3}(8 \%)$ Moringa oleifera leaf meal showing the best feed conversion ratio. This result signified that Moringa oleifera leaf meal had the capacity of improving efficiency of feed utilization at that level. The efficient utilization of the feed resulted in the highest body weight gain observed in broilers on $\mathrm{T}_{3}(1779.30 \mathrm{~g})$.

The results of feeding Moringa oleifera leaf meal on serum biochemical parameters of broiler chickens are shown in Table 5. There were significant differences $(\mathrm{P}<0.05)$ among the treatment groups in urea, cholesterol, glucose, calcium and Alkaline phosphatase values. However, there were no significant differences $(P>0.05)$ among the treatment groups in Aspartate transaminase values.

Serum urea content was significantly $(P<0.05)$ higher in birds fed control diet $\left(T_{1}\right)$ than those fed $10 \%$ MOLM. However, there was no significant difference $(P>0.05)$ between birds fed control diet and those fed $6 \%$ and $8 \%$ MOLM. The highest serum urea was observed in $T_{1}(13.50$ $\mathrm{mg} / \mathrm{dl}$ ) while the lowest serum urea value of $5.00 \mathrm{mg} / \mathrm{dl}$ was observed in $\mathrm{T}_{4}$. The serum urea values obtained in this study were within the normal range of 4.80 to $19.80 \mathrm{mg} / \mathrm{dl}$ 
reported by Kaneko et al. (1997) for birds and within the range of 10.20 to $29.74 \mathrm{mg} / \mathrm{dl}$ reported by Egu (2017) in Harco cocks except broiler chickens fed 10\% MOLM whose urea value was lower than the range. However, the urea values in his study were lower than the range of $30.46 \pm 2.51$ to $54.08 \pm 0.11 \mathrm{mg} / \mathrm{dl}$ reported by lheukwumere et al. (2006) in Nigerian chickens. This disparity in urea values may be attributed to differences in breed and nutritional status of the birds. It has been observed that serum urea content depends on both the quantity and quality of protein supplied in the diet (Iheukwumere and Herbert, 2002). Higher blood urea levels have been associated with poor protein quality or excess tissue protein catabolism associated with protein deficiency (Eggum, 1970).

Serum cholesterol content was significantly $(P<0.05)$ higher in birds fed control diet $\left(T_{1}\right)$ than those fed $6 \%, 8 \%$ and $10 \%$ MOLM which were similar $(P>0.05)$ to each other in serum cholesterol content. The lowest cholesterol value of $63.50 \mathrm{mg} / \mathrm{dl}$ was observed in birds fed $10 \% \mathrm{MOLM}$. The cholesterol values obtained in this study were within the normal range of 52 to $143 \mathrm{mg} / \mathrm{u}$ reported by Banerjee (2007) for birds except birds fed control diet $\left(T_{1}\right)$ whose cholesterol value $(164.00 \mathrm{mg} / \mathrm{dl})$ was higher than the normal range. The cholesterol values in this study were also within the range of 109 to $128(\mathrm{mg} / \mathrm{dl})$ reported by Egu (2017) for Harco cocks except birds fed control diet $\left(T_{1}\right)$ whose cholesterol value $(164.00 \mathrm{mg} / \mathrm{dl})$ was higher than the range and birds fed 10\% MOLM whose cholesterol value $(63.50 \mathrm{mg} / \mathrm{dl})$ was lower than the range. Cholesterol in the serum has been associated with the quantity and quality of fat supplied in the diet (Esonu et al., 2001).

Serum glucose content was significantly $(\mathrm{P}<0.05)$ higher in birds fed control diet than those fed $6 \%, 8 \%$ and $10 \%$ MOLM which were similar $(P>0.05)$ to each other in serum glucose values. Serum glucose level decreased as the level of Moringa oleifera leaf meal in the diets increased. The lowest value for serum glucose was observed in birds fed $10 \%$ MOLM $\left(\mathrm{T}_{4}\right)(84.50 \mathrm{mmol} / \mathrm{L})$. The serum glucose values obtained in this study were lower than the value of $167.8 \mathrm{mg} / \mathrm{u}$ reported by Kaneko et al. (1997) for birds and lower than the range of 132.60 to $176.40 \mathrm{mg} / \mathrm{dl}$ reported by Egu (2017) in Harco cocks. However, the glucose values obtained in this study were within the range of 75.60 to $100.50 \mathrm{mg} / 100 \mathrm{ml}$ reported by Egu (2010) in broiler fed slam weed (Chromoleana odorata) leaf meal except birds fed control diet $\left(T_{1}\right)$ whose glucose value $(142.50 \mathrm{mmol} / \mathrm{L})$ was higher than the range. Glucose is one of the metabolites measured as an indicator of the energy status of the animals.

Serum calcium content was significantly $(P<0.05)$ higher in birds fed $10 \%$ MOLM- based diet than those fed control diet $\left(T_{1}\right)$ which were similar $(P>0.05)$ to birds fed $6 \%$ MOLM- based diet. However, serum calcium contents were similar $(P>0.05)$ among birds fed $6 \%, 8 \%$ and $10 \%$ MOLM- based diets. The lowest value in serum calcium was observed in broiler chicken fed control diet $\left(T_{1}\right)$ (7.40 $\mathrm{mmol} / \mathrm{L}$ ). The serum calcium content increased as the level of Moringa oleifera leaf meal increased in the diets. The serum calcium values obtained in this study were slightly higher than the normal value of $7.10 \mathrm{mmol} / \mathrm{L}$ reported by Kaneko et al. (1997) for chickens, but lower than the range of 16.03 to $19.12 \mathrm{mmol} / \mathrm{L}$ reported by Egu (2016) in mature male turkeys. However, the serum calcium values obtained in this study were within the range of 8.06 to $8.94 \mathrm{mg} / \mathrm{dl}$ reported by Egu (2017) in Harco cocks except boiler chickens fed control diet $\left(T_{1}\right)$ whose calcium value $(7.40 \mathrm{mmol} / \mathrm{L})$ was lower than the range. This disparity in calcium values may not be unconnected to the differences in breed and nutritional status of the birds.

Serum Alkaline phosphatase content was significantly $(\mathrm{P}<0.05)$ higher in birds fed 6\% MOLM- based diet than those fed $8 \%$ MOLM- based diet. However, serum Alkaline phosphatase content were similar $(P>0.05)$ among birds fed control diet, $6 \%$, and $10 \%$ MOLM- based diets. The lowest serum Alkaline phosphatase value was observed in birds fed $8 \%$ MOLM-based diet $(123.50 \mu / L)$. Serum Alkaline phosphatase values obtained in this study were lower than the normal value of $482.5 \mathrm{iu} / \mathrm{L}$ reported by Kaneko et al. (1997) for chickens, but higher than the range of 73.60 to $81.00 \mathrm{iu} / \mathrm{L}$ reported by Egu (2017) for Harco cocks and higher than the range of 32.07 to 44.13 iu/L reported by Egu (2016) for mature male turkeys treated with gonadotrophin (Diclair $\AA$ ). This disparity may not be unconnected to the differences in breed, physiological and nutritional status of these birds. Alkaline phosphatase assay is useful in the diagnosis of obstructive liver disease (Murray et al., 2003).

Serum Aspartate transaminase contents were similar ( $P>0.05$ ) among birds fed control diet, 6\%, 8\% and 10\% MOLM-based diets. The birds recorded $89.00 \mathrm{iu} / \mathrm{L}$ across the treatments. This value of $89.00 \mathrm{iu} / \mathrm{L}$ was lower than the range of $178.40 \mathrm{iu} / \mathrm{L}$ reported by Kaneko et al. (1997) for chickens, but higher than the value of $31.00 \mathrm{i} / \mathrm{L}$ reported by Iheukwumere and Herbert (2002) for broiler chickens and lower than the value of $0.00 \mathrm{iu} / \mathrm{L}$ reported by Egu (2017) for Harco cocks.

Alanine transaminase was not detected among the treatment groups. This was in agreement with the report of Egu (2017) for mature Harco cocks. An increase in Alkaline phosphatase, Alanine transaminase and Aspartate transaminase values would signify necrosis or myocardial infarction which are all indicators of drug toxicity or harmful chemicals in the body (Nelson and Cox, 2005).

\section{Conclusion}

The results of this study have shown that Moringa oleifera leaf meal enhanced performance of the broiler chickens: weight gain, feed intake and feed conversion ratio compared to the control diet with the best performance at 
$8 \%$ inclusion level. Although the main intention of feeding the birds with MOLM was to improve performance, the action led to changes in serum biochemistry of the birds, but without any deleterious effects on these parameters. Glucose and cholesterol levels in the serum decreased as the level of Moringa oleifera leaf meal increased in the diet and this is good for maintenance of body homeostasis.

\section{CONFLICT OF INTEREST}

The authors declare that they have no conflict of interest.

\section{REFERENCES}

AOAC (2002). Official Methods of Analysis. Association of Official Analytical Chemists, Washington, D.C., USA, $17^{\text {th }}$ edition.

Ayssiwede, S. B., Dieng, A., Bello, H., Chrysostome, C. A. A. M., Hane, M. B., Mankor, A., Dahouda, M., Houinato, M. R., Hornick, J. L., \& Missohou, A. (2011). Effect of Moringa oleifera (Lam) leave meal incorporation in diets on growth performance, carcass characteristics an economic results of growing indigenous Senegal chickens. Parkistan Journal of Nutrition, 10(2), 1132-1145.

Baker, F.J., \& Silverton R. F. (1986). Introduction to Medical Laboratory Technology $6^{\text {th }}$ Edn. Butter-worth, England.

Banerjee, G. C. (2007). A Textbook of Animal Husbandry (8th edition). Oxford and IBH Publishing co PVT Ltd New Delhi India.

Ebenebe, C. L., Umegechi, A. C., \& Nweze, B. O. (2012). Comparison of haematological parameters and weight changes of broiler chicks fed different levels of Moringa oleifera diet. Inter J. Agric. Bio. Sci., 1, $23-25$.

Eggum, B. O. (1970). Blood urea measurement as a technique for assessing protein quality. British Journal of Nutrition, 29, 985-988.

Egu, U. N. (2010). Haematology, serum biochemistry and organ weight of finisher broilers fed slam weed (Chromoleana odorata) leaf meal. Journal of Agriculture, Biology and Food Research, 1(1), 282-292.

Egu, U. N. (2011). Effect of varying levels of NUTR-ZYM (Exogenous enzyme) supplemented rice milling waste on the performance, carcass and organ characteristics of broiler finisher birds. Journal of Food and Fibre Production 4(3): 344351.

Egu, U. N. (2016). Haematological and serum biochemical parameters of mature male turkeys treated with human menopausal gonadotrophin (Diclairß) for spermatogenesis. Inter. J. Vet. Sci., 5(4), 274-279.

Egu, U. N. (2017). Haematological and serum biochemical parameters of mature Harco cocks treated with human menopausal gonadotrophin (Diclair®) for spermatogenesis. International Journal of Environment, Agriculture and Biotechnology, 1-29(1), 429-436.

Esonu, B. O., Emenalom, O. O., Udedibie, A. B. I., Herbert, U., Ekpor, C. F., Okoli, I. C., \& Iheukwumere, F. C. (2001). Performance and blood chemistry of weaner pigs fed raw mucuna bean (Velvet bean) meal. Trop. Anim. Prod. Ivest., 4, 49-54.

Esonu, B. O., Iheukwumere, F. C., Emenalom, O. O., Uchegbu,
M. C., \& Etuk, E. B. (2006). Performance, nutrient utilization and organ characteristics of broilers fed Microdesimis puberula Leaf Meal. Livestock Research for Rural Development, 14(6). Available at http://www.Irrd.cipav.org.co/lrrd14/6/eson146.htm.

Ewuola, E. O. Jimoh, O. A., Atuma, O. V., \& Soipe, D. O. (2012). Haematological and serum biochemical responses of growing rabbits fed graded levels of Moringa oleifera leaf meals. Proceedings $10^{\text {th }}$ World Rabbit Congress - September $3^{\text {rd }}-6^{\text {th }}$ - Sharm El-sheikh - Egypt, Pp. 679-683.

Fuglie, L. (2009). New uses of Moringa studied in Nicaragua (EDN 68): Moringa Leaf 2009.

Fuglie, L. J. (2013). Moringa Tree: A Local Solution to Malnutrition. Church World Services Ltd. Senegal.

Gadzirayi, C. T., Masamba, B., Mupangwa, J. F. \& Washaye, S. (2012). Performance of Broiler Chickens fed on Mature Moringa oleifera Leaf Meals as a Protein Supplement to Soya bean Meal. International Journal of Poultry Science ,11(1), 510.

Gaia, S. (2010). Wonder tree 100 facts Moringa fact 04 exceptional animal feed Moringa as livestock feed and pet food. Moringa Mission Golden Valley Agricultural Research Trust 2010. Strengthening HIV/AIDS and food security mitigation mechanisms amongst small holder farmers in Botswana, Lesotho Namibia and Zambia: Phase 2 GART Animal Report. (2005)

Iheukwumere, F. C., \& Herbert, U. (2002). Physiological responses of broiler chickens to quantitative water restriction. Haematology and Serum Biochemistry. International Journal of Poultry Science, 2(2), 117-119.

Iheukwumere, F. C., Ndubuisi, E. C. Mazi, E. A. \& Egu, U. N. (2008). Performance, blood chemistry and carcass quality of broiler finisher chickens fed raw and processed soya bean seed meals. Animal Production Research Advances 4(2), 135139.

Iheukwumere, F.C., Abu, A. H., \& Ameh, M. (2006). Effect of human menopausal gonadotrophin on haematological and serum biochemical parameter of Nigerian indigenous chickens. International Journal of Poultry Science, 5(7), 632634.

John, C. M., \& Kenuleone, G. (2014). Effect of graded levels of Moringa oleifera leaf meal on growth performance and carcass characteristics of broilers. Global Journal of Animal Scientific Research, 2(2), 109-115.

Kaneko, J. J., Harvey, J. W., \& Bruss, H. I. (1997). Clinical Biochemistry of Domestic Animals $5^{\text {th }}$ Edition. Academic Press. San Diego, Carlifonia Pp. 885-905.

Kwedibana, J. E. (2008). Effect of Moringa oleifera Leaf meal on the growth rate of broilers. RM0875. Botswana College of Agriculture, Botswana, 2008.

Martin, E. A. (2007). Concise Medical Dictionary (7th ED.) Oxford. England. Oxford University Press.

Murray, R. K., Granner, D. R., Mayes, P. A., \& Rodwell, V. W. (2003). Herpers Illustrated Biochemistry. 25 ${ }^{\text {th }}$ Edn. Mc Graw Hill Companies, Inc. U.S.A. p. 693.

Nelson, D. L., \& Cox, M. M. (2005). Lehninger Principles of Biochemistry $4^{\text {th }}$ Edn. W.H. Freeman and Company New York. p. 119.

NRC (1994). National Research Council Nutrient Requirement for Poultry $9^{\text {th }}$ Edition.

Obi, I. U. (2002). Statistical Methods of Detecting Differences between Treatment Means. Snaap $16^{\text {th }}$ Ed., Enugu, Nigeria. Pp. 24 - 35.

Odoemelam, V. U., Nwaogu, K. O., Ukachukwu, S. N., Etuk, E. B., Etuk, I. F., Aladi, N. O., \& Ogbuewu, I. P. (2013). Growth 
response, carcass quality and organoleptic assessment of broiler chickens fed Ocimum gratissimum L Supplemented Diets. Int'L Journal of Agric. and Rural Dev., 16 (2), 1521-1528.

Olugbemi, T. S., Mutayoba, S. K., \& Lekule, F. P. (2008). Effect of Moringa (Moringa oleifera) inclusion in cassava based diets fed to broiler chickens. Int. J. Poult. Sci., 9(4), 363-367.

Omer, M. E., \& Hyder, E. A. (2016). The Effect of feeding different levels of Moringa Oleifera leaf meal on the performance and some blood parameters of broilers. International Journal of Science and Research, 5(3), 632-635.

Onu, P. N., \& Aniebo, A. O. (2011). Influence of Moringa oleifera Leaf Meal on the Performance and Blood Chemistry of Starter Broilers. Nigerian International Journal of Food, Agriculture and Veterinary Science. 1(1), 38-44.

Onu, P. N., \& Otuma, M. O. (2010). Utilization of heat-treated sheep dropping in the diets of broiler finisher chickens. Int. J. of Poult. Sci., 7(2), 169-173.
Rej, R., \& Hoder, M. (1983). Alanine transaminase. In: Methods of Enzymatic Analysis $3^{\text {rd }}$ Edition H.U. Bergmeyer, I. Berg Meyer and M. grassal (eds.). Weinhen Velag. Chemie 1. Pp. 3416-433.

Sarwatt, S. V., Kapange, S. S., \& Kakengi, A. M. V. (2012). Substituting sunflower seed-cake with Moringa oleifera leaves as supplemented goat feed in Tanzania. Agroforestry systems, 56(3) 241-247.

Steel, R. G. D., \& Torri, J. H. (2006). Principle and Procedures of Statistics. A Biometric Approach $3^{\text {rd }}$ Ed. Mc. Graw-Hill Book Co. Inc. New York.

Yang, R. Y., \& Tsou, S. C. S. (2006). Enhancing iron Bioavailability of vegetables through proper preparation principles and applications. Journal of International cooperation, 1, 107119. 